\title{
Hambatan Pengimplementasian Kurikulum 2013 Pada Proses Pembelajaran Universalime Islam (PAI)
}

\author{
Devfy Kartikasari \\ Universitas Islam Negeri (UIN) Sunan Kalijaga Yogyakarta \\ Kdevfy@gmail.com \\ Zulfikar Mujib \\ Universitas Islam Negeri (UIN) Sunan Kalijaga Yogyakarta \\ zulfikarmujib@gmail.com
}

\begin{abstract}
This study aims to analyze the problems in the learning process of the Islamic Universalism (PAI) subject and the challenges in implementing the 2013 curriculum. In addition, this study is useful as a reference in finding solutions to problems in implementing the 2013 curriculum in the learning process of Islamic Universalism (PAI) subjects) at SMA Budi Mulia Dua Yogyakarta. This research method uses qualitative methods with a case study approach. The data collection techniques used was interviews, observation, and documentation. The results of data collection are then compared to become material for analysis. As a result, the implementation of the 2013 curriculum on the subject of Islamic Universalism (PAI) was carried out by involving the principal, teachers, students, learning resources, and related infrastructure. The implementation of the 2013 curriculum in the UI/PAI subjects encountered obstacles, namely because the school was a school that combined the Cambridge curriculum and the national curriculum, it needed students who were able to meet the standards of the two curricula, while a case was found in the field that there was a gap in student readiness in reading and writing Quran. The solution to this problem, the school has an effort, namely by carrying out the School Literacy Movement and the Quran corner.
\end{abstract}

Keywords: Resistance, 2013 Curriculum, Learning, Islamic Education

\begin{abstract}
Abstrak: Penelitian itu bertujuan untuk menganalisis permasalahan dalam proses pembelajaran mata pelajaran Universalisme Islam (PAI) dan tantangan dalam menerapkan kurikulum 2013. Selain itu, penelitian ini berguna sebagai rujukan dalam mencari solusi atas permasalahan penerapan kurikulum 2013 dalam proses pembelajaran mata pelajaran Universalisme Islam (PAI) di SMA Budi Mulia Dua Yogyakarta. Metode penelitian ini menggunakan metode kualitatif dengan pendekatan studi kasus. Teknik pengumpulan data yang digunakan adalah wawancara, observasi, dan dokumentasi. Hasil pengumpulan data, kemudian dibandingkan untuk menjadi bahan analisis. Hasilnya, pengimplementasian kurikulum 2013 pada mata pelajaran Universalisme Islam (PAI) dilakukan dengan melibatkan kepala sekolah, guru, peserta didik, sumber belajar, dan sarana prasarana yang terkait. Pengimplementasian kurikulum 2013 pada mata pelajaran UI/PAI mengalami hambatanyaitu dikarenakan sekolah tersebut adalah sekolah yang memadukan antara kurikulum Cambridge dan kurikulum nasional, maka dibutuhkan
\end{abstract}

Belajea: Jurnal Pendidikan Islam Vol. 5, No 2, 2020; 181-198

p-ISSN 2548-3390; e-ISSN 2548-3404, DOI:10.29240/belajea.v5i2.1606

http://journal.iaincurup.ac.id/index.php/belajea 
siswa yang mampu dengan standart kedua kurikulum tersebut, sedangkan ditemui kasus dilapangan bahwa adanya kesenjangan kebisaan siswa dalam Baca Tulis AlQuran. Solusi dari permasalahan tersebut, sekolah mempunyai upaya yaitu dengan melakukan Gerakan Literasi Sekolah dan Quran corner.

Kata Kunci: Hambatan, Kurikulum 2013, Pembelajaran, PAI

\section{Pendahuluan}

Pendidikan adalah suatu hal yang tidak bisa dipisahkan dari kehidupan. Pendidikan digunakan sebagai bekal untuk menjadi manusia yang utuh. Begitu pentingnya pendidikan maka suatu negara pasti memeprdulikan pendidikan bagi bangsanya. Kehidupan masyarakatpun tidak bisa lepas dari yang namanya pendidikan itu sendiri. Pendidikan saat ini justru menjadi kebutuhan bagi masyarakat itu sendiri. Pendidikan adalah usaha pendewasaan manusia seutuhnya (lahir dan batin), baik oleh orang lain maupun oleh dirinya sendiri, dalam arti tuntutan agar anak didik memiliki kemerdekaan berpikir, merasa, berbicara, dan bertindak, serta percaya diri dengan penuh rasa tanggung jawab dalam setiap tindakan dan perilaku kehidupan sehari-hari.

Pendidikan adalah sebuah usaha untuk mengembangkan segala aspek kualitas diri pada manusia.Pendidikan adalah aktiitas yang dilakukan secara sengaja untuk mencapai pada tujuan dan menghubungkan dengan berbagai faktor sehingga akan menjadi bentuk sistem yang saling berpengaruh. Istilah dalam pendidikan tidak terlepas dari tiga istilah yaitu at-tarbiyah, at-ta'lim dan atta'dib.Masalah terkait pendidikan selalu saja menjadi hal yang menarik untuk dibahas tidak terkecuali dengan negara maju sekalipun itu. Pendidikan selalu menjadi topik yang selalu hangat untuk dibahas. diIndonesia sendiri, sejak awal kemerdekaan hingga saat ini tidak henti-hentinya membahas mengenai pendidikan. ${ }^{1}$

Pendidikan merupakan suatu hal yang sangat penting dalam kehidupan manusia, karena melalui pendidikan tersebut manusia dapat menumbuh kembangkan potensi yang ada pada dirinya. Manusia dikatakan sebagai mahluk sosial karena memiliki kemampuan berinteraksi dengan lingkungannya baik lingkungan fisik, maupun lingkungan sosial. Maka dari pada itu, diperlukan cara ataupun metode yang sesuai serta tidak hanya menjadikan proses belajar mengajar menarik akantapi dapat memberikan kesempatan bagi peserta didik

${ }^{1}$ Baharudin, Gagasan Ivan Illich Tentang Pendidikan Dalam Buku Deschooling Society. Terampil, 2 Januari, 2014, hlm. 118. 
untuk menuangkan kreatifitasnya dan selalu ikut aktif selama kegiatan belajar berlangsung. ${ }^{2}$

Masalah dalam pendidikan sangatlah beragam termasuk dalam segi komponennya. Komponen merupakan bagian dari sistem pendidikan itu sendiri tidak terkecuali dengan kurikulum. Maka tidak heran jika kurikulum menjadi hal yang sangat penting untuk dibenahi ketika terjadi hal yang tidak sesuai. Pendidikan itu berjalan dengan adanya kurikulum sebagai perencana.Maka jika pendidikan secara luas berubah atau berkembang, maka komponen atau alat didalamnya termasuk kurikulum juga ikut berubah atau berkembang. ${ }^{3}$ Mendapatkan pendidikan merupakan hak bagi setiap manusia. Pendidikan akan menjadikan manusia sempurna kehidupan dan penghidupannya dapat selaras dengan kodrat manusia lebih baik dari sebelumnya karena pendidikan akan membentuk watak sehingga menjadi manusia yang aktif dan kreatif. Pendidikan juga akan menjadikan individu dapat bersaing dengan berbagai orang dengan latar belakang negara yang berbeda. ${ }^{4}$

Perubahan merupakan suatu keniscayaan yang terjadi di dunia ini. Pendidikan sebagai penyeimbang tatanan sosial tidak lepas dari perubahan. Tuntutan kualitas pendidikan yang bermutu menjadi sebagian yang mesti dikembangkan demi merespon persaingan dunia yang semakin kompetetif. Melalui konsep perubahan kurikulum dari KTSP menjadi Kurikulum 2013, pemerintah melalui Kemendikbud mencoba merelevansikan gejala perubahan yang terjadi saat ini dengan mengembangkan mutu pendidikan yang lebih baik. Saat ini hampir semua sekolah menerapkan Kuikulum 2013 baik itu sekolah pada umumnya, sekolah inklusi, bahkan sekolah luar biasa yang notabene mereka adalah anak-anak yang memerlukan perlakuan khusus dalam pembelajaran. $^{5}$

Perubahan-perubahan yang terjadi dalam semua aspek pendidikan digunakan untuk memperbaiki pendidikan itu sendiri. Misalnya dengan cara

${ }^{2}$ Muhibbin -Muhibin and M. Arif Hidayatullah, 'Implemntasi Teori Belajar Konstruktivisme Vygotsky Pada Mata Pelajaran PAI Di SMA Sains Qur`An Yogyakata’, Belajea; Jurnal Pendidikan Islam 5, no. 1 (22 May 2020): 113, https://doi.org/10.29240/belajea.v5i1.1423. hlm. 114.

${ }^{3}$ Udin Syaefudin dan Abin Syamsudin Makmun, Perencanaan Pendidikan (Bandung: Remaja Rosdakarya, 2005), hlm. 51.

${ }^{4}$ Hidayatul Muamanah and. Suyadi, 'Pelaksanaan Teori Belajar Bermakna David Ausubel Dalam Pembelajaran Pendidikan Agama Islam', Belajea; Jurnal Pendidikan Islam 5, no. 1 (22 May 2020): 161, https://doi.org/10.29240/belajea.v5i1.1329. Hlm. 162.

${ }^{5}$ Achmad Dahlan Muchtar, 'IMPLEMENTASI KURIKULUM PAI 2013 PADA ANAK BERKEBUTUHAN KHUSUS DI SMPLB BHAKTI KENCANA YOGYAKARTA', Edumaspul - Jurnal Pendidikan 2, no. 1 (28 February 2018): 70-78, https://doi.org/10.33487/edumaspul.v2i1.16. hlm. 71. 
mempertahankan konsep pendidikan yang lama dan disesuaikan dengan konsep pendidikan yang baru. Hal ini diupayakan untuk memaksimalkan ketercapaian tujuan pendidikan. Islam sendiri mengajarkan kepada pengikutnya untuk selalu menerima perubahan asalkan perubahan tersebut kearah yang baik dan positif. Kita sebagai muslim dituntut untuk selalu memperluas wawasan dan membentuk sikap yang bertoleransi terhadap segala bentuk perubahan tetapi, perubahan inilah yang seharusnya disaring dan diambil yang baik saja. Karena perubahan inilah, maka tidak bisa jika hanya beberapa sub bab pendidikan saja yang berubah, melainkan seluruh aspek pendidikanpun turut menyertai perubahan ini. Hal ini tentunya akan berdampak kepada kurikulum yang digunakan selaku perencana dari sebuah pendidikan itu sendiri. Jika kita tarik sejarah, maka pendidikan nasional sudah banyak sekali mengalami perubahanperubahan. Pendidikan islam, adalah subsistem dari pendidikan nasional itu sendiri, tentunya juga akan mengalami perubahan didalam kurikulumnya. ${ }^{6}$

Pada awal diberlakukannya Kurikulum 2013 ini (tahun ajaran 2014/2015) ternyata banyak menuai masalah. Menurut Alawiyah (2014, hlm. 9) bahwa persiapan Kurikulum 2013 ini dinilai terlalu terburu-buru dan tidak mengacu pada hasil kajian yang sudah matang berdasarkan hasil evaluasi KTSP, dan kurang memperhatikan kesiapan satuan pendidikan dan guru. Hal tersebut tentunya membawa masalah yang besar apabila guru sebagai implementator kurikulum tidak mendapatkan bentuk pelatihan yang matang dari Pemerintah. Berdasarkan surat keputusan Kementerian Pendidikan dan Kebudayaan mengenai pelaksanaan Kurikulum 2013, diputuskan bahwa sekolah yang telah menerapkan kurikulum 2013 selama tiga semester maka dapat melanjutkan kurikulum tersebut, sedangkan sekolah yang baru menerapkan selama satu semester maka kembali lagi menggunakan kurikulum KTSP. Namun ternyata kebijakan tersebut tidak berlaku bagi mata pelajaran Pendidikan Agama Islam dan Budi Pekerti di sekolah yang berada di Provinsi Jawa Barat yang tetap menggunakan kurikulum 2013.

SMA Budi Mulia adalah salah satu sekolah internasional yang ada di Yogyakarta, otomatis didalam kurikulumnya akan berbeda dengan sekolahsekolah lainnya. Perbedaan itu terletak pada kurikulum yang digunakan disekolah. SMA Budi Mulia ini menggunakan kurikulum khas sekolah dipadukan

${ }^{6}$ Muhammad Irsad, 'Pengembangan Kurikulum Pendidikan Agama Islam Di Madrasah' .Iqra, Vol 2, No. 1, Nov 2016, hlm. 232

${ }^{7}$ Humaira Ulfah, Edi Suresman, and Abas Asyafah, 'STUDI REALITAS IMPLEMENTASI KURIKULUM 2013 PADA MATA PELAJARAN PAI DAN BUDI PEKERTI JENJANG SMA (Studi Deskriptif pada Berbagai Klasifikasi Guru SMA di Kota Bandung Tahun 2015)', TARBAWY: Indonesian Journal of Islamic Education 2, no. 1 (5 May 2015): 58, https://doi.org/10.17509/t.v2i1.3378. hlm. 59 
dengan Kurikulum Cambridge yang kemudian di sesuaikan dengan kurikulum nasional. Pada penelitian yang dilakukan ini, peneliti hanya focus pada implementasi kurikulum 2013 pada proses pembelajarannya saja. Peneliti mengamati bahwa terdapat kesenjangan antara siswa yang sudah bisa membaca Al-Quran dengan yang belum bisa. Untuk mengatasi hal ini, tentunya sekolah mempunyai formula tersendiri dalam mencari solusinya yang kemungkinan masalah ini tidak akan terselesaikan jika tidak sekolah yang dianggap tahu tidak menyelesaikan masalahnya sendiri. Hal ini tentunya akan berbeda keadaan dengan sekolah yang lainnya. Maka disinilah tantangan kurikulum nasional (kurikulum 2013) yang dianggap kurang responsif terhadap permasalahan yang beragam. Fokus penelitian yang akan diteliti ialah pengimplemnetasian kurikulum 2013 dalam komponen metode atau strategi pembelajaran di kelas khusus pada mata pelajaran PAI dengan membahas mengenai hambatan dan solusinya.

\section{Kurikulum 2013 Pada Mata Pelajaran PAI}

Kata kurikulum, berasal dari bahasa latin yaitu Curriculum yang berarti a running. Sedangkan dalam bahasa perancis yaitu Courier yang berarti to run. Yang selanjutnya istilah tersebut diartikan dengan sejumlah mata pelajaran yang harus ditempuh siswa untuk mendapatkan ijazah dan gelar tertentu. ${ }^{8}$ Pengertian yang disebutkan diatas menimbulkan pengertian bahwa kurikulum hanya terbatas pada sejumlah mata pelajaran saja. Kegiatan selain yang berhubungan dengan pembelajaran dikelas bukan termasuk dalam kategori kurikulum. Padahal kegiatan disekolah itu bukan hanya sebatas belajar dikelas saja, melainkan ada juga kegiatan diluar sekolah. Hal ini berhubungan dengan pandangan tradisional yang menyatakan bahwa kurikulum memang hanya mata pelajaran yang ditempuh siswa dikelas.

Pandangan mengenai persepsi tersebut tidaklah salah, melainkan pengertian tersebut hanya mengklasifikasikan antara kegiatan kurkuler dengan ekstrakurikuler dan kokurikuler. Kegiatan kurikuler inilah yang dimaksud kuurikulum yaitu mempelajari sejumlah mata pelajaran wajib. Sedangkan, kegiatan kokurikuler dan ekstrakurikuler sebagai kegiatan penyerta saja. Misalkan jika ada pelajaran kimia, inilah kurikuler lalu kegiatan di laboratorium adalah kegiatan kokurikulernya. ${ }^{9}$

Berbeda halnya dengan pandangan modern yang mengartikan kurikulum adalah bukan hanya sekedar rancangan mata pelajaran, melainkan semua aktivitas yang terjadi dalam proses pendidikan di sekolah. Kurikulum dalam

\footnotetext{
${ }^{8}$ Salahuddin, Filsafat Pendidikan, hlm. 67.

${ }^{9}$ Ahmad Tafsir, Ilmu Pendidikan Islami (Bandung: Remaja Rosdakarya, 2016), hlm. 81
} 
pandangan modern sangat luas artinya yaitu semua yang memberikan pengalaman belajar siswa juga dianggap sebagai kurikulum. Seperti pramuka, olahraga dan apapun yang bermanfaat bagi siswa adalah kurikulum.

Atas dasar anggapan ini ternyata pengertian dalam konsep modern memberikan kesimpulan bahwa apapun yang bisa mempengaruhi pendewasaan anak bukan hanya mempelajari mata pelajaran saja adalah kurikulum, termasuk proses interaksi dengan lingkungannya. Dari pengertian tersebut, maka sekolah adalah sebagai miniature masyarakat. Jika orang ingin mencari gambaran masyarakat tersebut, maka amatilah sekolah-sekolahnya. Jika sekolah mampu berdisiplin, maka seperti itulah gambaran masyarakatnya. Jika terjadi yang buruk misalnya penipuan dalam sekolah, maka kira-kira seperti itulah gambaran masyarakatnya ${ }^{10}$. Kurikulum adalah progam pendidikan yang diselenggarakan sekolah yang meliputi segala sesuatu yang bisa membentuk pribadi siswa yang diharapakan bisa mencapai tujuan pendidikan. ${ }^{11}$

Selanjutnya, berdasarkan uraian diatas, berarti kurikulum itu luasnya seluas masyarakat dan kehidupannya. Hal ini tentunya akan membingungkan karena terlalu luas. Maka Hilda Taba menyimpulkan isi kurikulum. Menurutnya isi kurikulum dapat dikelompokkan menjadi empat saja yaitu, tujuan, isi, pola belajar-mengajar, dan penilaian. Hal ini sama yang dikemukakan oleh Ralph W. Tyler. Oleh karena itu, bila orang ingin membuat atau menilai kurikulum, perhatian yang difokuskan tersebut tertuju pada empat pertanyaan, diantaranya: (1) Apakah tujuan dari pengajaran itu sendiri? Pengajaran disini bermaksa pengajaran dalam hal yang luas. (2) Pengalaman belajar apa yang disiapkan untuk mencapai tujuan? (3) Bagaimana pengalaman belajar itu dilaksanakan? (4) Bagaimana menentukan bahwa tujuan telah tercapai?

Maka demikian, kurikulum sangat berhubungan erat dengan tujuan pendidikan. Dimana untuk mencapai tujuan, maka dibutuhkan kurikulum sebagai perencananya. Begitupun kehidupan kita sehari-hari, apapun yang menjadi tujuan kita haruslah direncanakan terlebih dahulu. Tujuan seharusnya juga diukur untuk mengetahui apakah sudah tepat atau belum, maka tujuanpun harusnya direvisi. Begitu pun jika dikaitkan dengan pendidikan. Jika kurikulum sebagai perencana dianggap kurang sesuai maka harusnya direvisi. ${ }^{12}$

Menurut Muhaimin, Kurikulum berfungsi sebagai: (1) Kurikulum sebagai progam studi; sekumpulan mata pelajaran yang dipelajari siswa. (2) Kurikulum sebagai konten;isi materi dalam buku juga berisi informasi dan data yang

${ }^{10}$ Ibid., hlm. 81-82.

${ }^{11}$ Syamsul Bahri, 'Pengembangan Kurikulum Dasar dan Tujuannya', Jurnal Ilmiah Islam Futura Agustus 2011, hlm. 20.

${ }^{12} \mathrm{Ahmad}$ Tafsir, Ilmu Pendidikan Islami..., hlm. 82 
mendukung sebagai sumber belajar siswa. (3) Kurikulum sebagai kegiatan berencana; sebagai agenda perencanaan dalam pembelajaran untuk mencapai tujuan pendidikan. (4) Kurikulum sebagai hasil belajar, kumpulan tujuan yang diperoleh dalam proses pembelajaran.(5) Kurikulum sebagai reproduksi kultural; sebagai refleksi dari budaya dari masyarakat yang kemudian menjadi bahan pelajaran bagi siswa untuk dipelajari. (6) Kurikulum sebagai pengalaman belajar; pengalaman belajar ini direncanakan oleh sekolah. (7) Kurikulum sebagai produksi; sekumpulan tugas yang harus dikerjakan untuk mencapai tujuan. ${ }^{13}$

Kurikulum adalah alat untuk mencapai tujuan pendidikan. Karenanya, kurikulum mempunyai bagian-bagian penting dalam mencapai tujuan pendidikan itu sendiri. Maka dari itu, kurikulum mempunyai bagian-bagian penting. Bagianbagian penting dalam kurikulum inilah yang dinamakan komponen. Menurut Hasan Langulung ada empat komponen utama kurikulum yaitu:tujuan pendidikan, mata pelajaran, Metode dan penilaian. ${ }^{14}$ Kurikulum adalah hal yang dinamis, bukanlah statis. Konsep kurikulum itu sendiri dapat diubah sesuai dengan perkembangan zaman dan teknologi yang ada. Oleh karenanya, dalam merumuskan kurikulum dibutuhkan pertimbangan yang matang sebelum diterapkan. Faktor yang harus dipertimbangkan antara lain, filosofis, sosiologis, psikologis dan lain-lain.Kurikulum fungsinya adalah sebagai pedoman ketika melaksanakan kegiatan pendidikan dan dilaksanakan oleh pihak-pihak yang terkait didalamnya. ${ }^{15}$

Penelitian ini akan berfokus pada komponen kurikulum metode atau stategi, karena komponen strategi/metode adalah komponen yang paling sesuai dengan pengimplementasian dalam proses pembelajaran. Kita tahu bahwa dalam Kurikulum K13 edisi revisi ada empat komponen penting yang saling berhubungan satu dengan yang lainnya. Keempat komponen tersebut adalah tujuan, isi/materi, strategi/metode, dan evaluasi. Tujuan kurikulum K13 ada beberapa perspektif diantara berdasarkan Pendidikan Nasional, Institusional, kurikuler, dan tujuan pembelajaran. Komponen isi dalam K13 yang dimaksud disini adalah harus sesuai dengan jenjang pendidikan. Komponen strategi/metode itu mencakup rencana pembelajaran yang digunakan sebagai alat untuk mencapai tujuan pendidikan. Dalam komponeen ini, pendidik dituntut bekerja aktif sehingga pembelajaran bisa berjalan dengan baik. Komponen yang terakhir dalam K13 adalah evaluasi hasil belajar. Evaluasi digunakan sebagai pengukur dan juga pengolah data dan informasi untuk

${ }^{13}$ Mahmud. Pemikiran Pendidikan Islam (Bandung: Pustaka Setia, 2011), hlm. 107-108.

${ }^{14}$ Ramayulis, Ilmu Pendidiakan Islam (Jakarta: Kalam Mulia, 2015), hlm. 234.

${ }^{15}$ Otang Kurniaman and Eddy Noviana, 'Penerapan Kurikulum 2013 dalam Meningkatkan Keterampilan, Sikap, dan Pengetahuan', Primary: Jurnal Pendidikan Guru Sekolah Dasar 6, Vol. 6 No. 2, Oktober 2017, hlm. 390 
memutuskan suatu kebijakan baru jika diketahui hasil yang dicapai kurang maksimal. ${ }^{16}$

Pada awal diberlakukannya Kurikulum 2013 (tahun ajaran 2014/2015) ternyata banyak menuai masalah. Menurut Alawiyah (2014, hlm. 9) bahwa persiapan Kurikulum 2013 ini dinilai terlalu terburu-buru dan tidak mengacu pada hasil kajian yang sudah matang berdasarkan hasil evaluasi KTSP, dan kurang memperhatikan kesiapan satuan pendidikan dan guru. Hal tersebut tentunya membawa masalah yang besar apabila guru sebagai implementator kurikulum tidak mendapatkan bentuk pelatihan yang matang dari Pemerintah. Berdasarkan surat keputusan Kementerian Pendidikan dan Kebudayaan mengenai pelaksanaan Kurikulum 2013, diputuskan bahwa sekolah yang telah menerapkan kurikulum 2013 selama tiga semester maka dapat melanjutkan kurikulum tersebut, sedangkan sekolah yang baru menerapkan selama satu semester maka kembali lagi menggunakan kurikulum KTSP. Namun ternyata kebijakan tersebut tidak berlaku bagi mata pelajaran Pendidikan Agama Islam dan Budi Pekerti di sekolah yang berada di Provinsi Jawa Barat yang tetap menggunakan kurikulum 2013.

Berdasarkan Peraturan Pemerintah Nomor 55 Tahun 2007 tentang Pendidikan Agama yang dilaksanakan oleh Menteri Agama dan Permendikbud Nomor 160 Tahun 2014 bahwa Kurikulum 2013 tidak diberhentikan secara substansial menyatakan bahwa: “(1) Mata Pelajaran Pendidikan Agama Islam dan Budi Pekerti tetap mengimplementasikan Kurikulum 2013 disemua sekolah; (2) Proses pembelajaran menggunakan pendekatan saintifik dengan alokasi waktu sesuai dengan kurikulum 2013 dan proses penilaian disesuaikan dengan kebijakan satuan pendidikan masing-masing; (3) Ke-menterian Agama Kabupaten/Kota terus melaksanakan kegiatan Bimbingan Teknis (BIMTEK) Kurikulum 2013”.

Mata pelajaran Pendidikan Agama Islam dan Budi Pekerti didalam Kurikulum 2013 mengandung pengertian sebagai suatu bidang studi yang dikembangkan di sekolah melalui proses pembelajaran dan pembinaan perkembangan jasmani maupun rohani peserta didik oleh seorang pendidik hingga mencapai tujuan pembelajaran yang diinginkan dengan pendidikan berbasis karakter yang terintegrasi. Kurikulum sebagai rencana tertulis harusmampu diimplementasikan oleh guru di lapangan melalui proses pembelajaran. Guru sebagai implementator kurikulum selama di dalam kelas tentunya harus mengikuti syarat/aturan yang telah dibuat oleh pemerintah, agar proses pembelajaran dapat berlangsung dengan efektif dan efisien. Menurut Permendikbud Nomor 65 Tahun 2013 Bab IV (dalam Abidin, 2014, hlm. 297)

${ }^{16}$ Https://juharti.wordpress.com diakses pada 22 November 2019 
tentang Pelaksanaan Pembelajar-an, disebutkan bahwa: "Di dalam persyaratan pelaksanaan proses pembelajaran, alokasi waktu jam tatap muka mata pelajaran PAI di SMA ialah selama 3x45 menit dan penggunaan buku teks pelajaran digunakan untuk meningkatkan efektivitas dan efesiensi yang jumlahnya disesuaikan dengan kebutuhan peserta didik.

Selain dari itu pun, pengelolaan kelas harus dilaksanakan oleh seorang guru dengan memperhatikan halhal sebagai berikut: (1) Guru menyesuaikan pengaturan tempat duduk sesuai dengan karakteristik pembelajaran; (2) Guru wajib menggunakan kata yang santun, lugas dan dapat didengar secara keseluruhan oleh siswa dengan intonasi yang jelas; (3) Guru menciptakan ketertiban dan kenyamanan selama di dalam kelas; (4) Guru memberikan penguatan dan umpan balik terhadap respon dan hasil belajar siswa serta mendorong dan menghargai peserta didik untuk dapat bertanya dan mengemukakan pendapat; (5) Guru berpakaian sopan, bersih dan rapih; (6) Pada tiap awal semester, guru menjelaskan kepada peserta didik silabus mata pelajaran; (7) Guru memulai dan mengakhiri proses pembelajaran sesuai dengan waktu yang dijadwalkan. ${ }^{17}$

\section{Implementasi Pengembangan Kurikulum 2013 PAI Dalam Proses KBM}

Tujuan, isi, evaluasi dan metode merupakan komponen dari kurikulum, yang saling terkait satu sama lain. Kurikulum sebagai guiding instruction juga merupakan antisipatori dan bukan hanya sebagai reportial. Oleh karena itu, kurikulum merupakan suatu hal yang sangat menentukan atau paling tidak sebagai antisipasi/pencegahan terhadap sesuatu yang akan terjadi. ${ }^{18}$ Dalam penelitian ini, fokus kurikulum yang dibahas adalah pada prosesnya, yaitu proses pembelajaran PAI dikelas.

Untuk dapat diterapkan dikelas, kurikulum 2013 pada mata pelajaran PAI tentunya akan melibatkan beberapa personal, diantaranya ada kepala sekolah, guru, siswa, sumber belajar, dan sarana prasarana pendukung lainnya. Berhasil tidaknya proses pembelajaran dikelas menjadi indikator dikatakan sukses tidaknya kurikulum. Menurut Sujana, berpendapat bahwa belajar dan mengajar adalah dua hal yang tidak bisa dipisahkan. Belajar adalah hal yang

${ }^{17}$ Ulfah, Suresman, and Asyafah, 'STUDI REALITAS IMPLEMENTASI KURIKULUM 2013 PADA MATA PELAJARAN PAI DAN BUDI PEKERTI JENJANG SMA (Studi Deskriptif pada Berbagai Klasifikasi Guru SMA di Kota Bandung Tahun 2015)'. Hlm. 60-62

${ }^{18}$ Siswanto Siswanto and Eli Susanti, 'Manajemen Pengembangan Kurikulum Sekolah Inklusi', Tadbir: Jurnal Studi Manajemen Pendidikan 3, no. 2 (24 November 2019): 113, https://doi.org/10.29240/jsmp.v3i2.927. 
dilakukan peserta didik, sedangkan mengajar adalah hal yang dilakukan pendidik. $^{19}$

Di SMA Budi Mulia salah satu perbedaan yang mencolok disini adalah dalam hal perbedaan nama dari PAI menjadi UI (Universalisme Islam), selain itu adalah tujuan dari setiap pembelajarannya adalah siswa mampu memiliki soft skills setelah adanya pembelajaran. Peneliti secara langsung ikut dalam proses pembelajaran yang dilakukan dikelas. Proses pembelajaran diawali dengan hal tidak jauh berbeda dengan sekolah lain yaitu salam, guru memberi motivasi, lalu dimulai dengan budaya literasi dengan membaca Al-Quran atau bisa Hadist, buku bacaan bahkan novel. Setelah mereka mmebaca Al-Quran, guru menunjuk siswa untuk memilih satu ayat untuk dibacakan lagi dan menurut siswa ayat tersebut menarik. Hal ini dilakukan untuk mempertajam kecintaan mereka terhadap Al-Quran, dan juga melatih kebiasaan membaca Al-Quran siswa.

Sekolah ini sudah mempunyai sarana dan prasarana yang memadai sehingga pembelajaran tidak monoton fokus kepada guru dan papan tulis saja. Proses membaca Al-Quran misalnya, bukan hanya sekedar dibaca bersama tetapi guru juga merangsang setiap individu untuk mau membaca lalu memahami makna kandungannya. Dengan membiasakan membaca Al-Quran setiap hari maka akan menumbuhkan kecintaan mereka terhadap Al-Quran. Dalam proses pembelajaran PAI dikelas, metode tidak kalah penting diperhatikan dalam proses belajar-mengajar dikelas. Metode digunakan sebagai cara dalam menerapkan rancangan yang sudah dibuat. Ciri metode yang baik adalah yang baik adalah (1) mampu membangkitkan motivasi, minat dan gairah peserta didik. (2) Metode itu mampu menjamin berkembangnya sikap murid. (3) metode tersebut mampu mewujudkan hasil karya. (4) metode mampu membuat siswa ingin belajar lebih lanjut. (5) metode mampu menambah ilmu siswa. (6) metode mampu meniadakan verbalitas. (7) Metode yang digunakan mampu mengembangkan nilai-nilai serta sikap siswa. ${ }^{20}$

Dalam proses pembelajaran PAI di SMA Budi Mulia dua Yogyakarta, metode yang digunakan sangatlah beragam mulai dari kolaboratif, yaitu kegiatan yang memungkinkan siswa dengan siswa lainnya saling berkolaborasi untuk menyelesaikan tugasnya dengan menggunakan media video yang nantinya akan ditampilkan pada layar LCD untuk bisa dinilai oleh teman kelompok yang lainnya. Dari kegiatan yang dilakukan dikelas, sudah bisa dikatakan memenuhi

${ }^{19}$ Rosmiaty Azis, 'Implementasi Pengembangan Kurikulum', Inspiratif Pendidikan. Volume VII, Nomer 1, Januari-Juni 2018, hlm. 45-49

${ }^{20}$ Lisa Diyah Ma'rifataini, 'Implementasi Metode Pembelajaran Pendidikan Agama Islam (Pai) di Sekolah Menengah Atas Negeri (SMA) 11 Bandung', EDUKASI: Jurnal Penelitian Pendidikan Agama dan Keagamaan. hlm. 113-14 
tujuh ciri metode yang baik.Guru juga menggunakan metode ceramah untuk menjelaskan materi. Guru sangat diharapkan berperan aktif dalam menentukan strategi/metode pembelajaran dikelas, karena metode yang sesuai akan mengantarkan kepada tujuan pendidikan yang dirumuskan. Dalam pembelajaran PAI dikelas, juga tampak guru mengajak interaksi siswa dengan baik, sehingga siswa tidak pasif dikelas. Guru bisa masuk kedalam dunia siswa sehingga mereka merasa bahwa pembelajaran yang dilakukan sangatlah tanpa beban.

\section{Hambatan Pengimplementasian Kurikulum 2013 Mata Pelajaran PAI Dalam KBM}

Teori hanya akan sekedar teori jika tidak diimplementasikan dalam kehidupan sehari-hari. Seperti halnya dalam proses pembelajaran PAI sendiri, membutuhkan pengimplementasian supaya teori yang diberikan bisa dibuktikan secara langsung. Tidak bisa dipungkiri bahwa proses pengimplementasian tidaklah semudah membalik telapak tangan. Dalam proses pengimplementasian, tentunya akan menghadapi hambatan-hambatan sebagai penghalang tercapainya tujuan pendidikan. Tantangan juga dihadapi dalam proses pembelajaran Universalime Islam (PAI) di SMA Budi Mulia Dua Yogyakarta. Menurut guru mata pelajaran PAI sendiri, hambatanterberat saat ini dihadapi adalah adanya kesenjangan antara siswa yang mampu membaca Al-Quran dan yang belum mampu membaca Al-Quran. Hal ini dikarenakan siswa-siswi yang bersekolah di sekolah tersebut sangatlah heterogen. Latar belakang siswa berbeda antara satu dengan yang lainnya. Ada beberapa siswa yang dari sekolah dasar, dan ada juga yang berasal dari madrasah ibtidaiyah. Sedikit banyak faktor asal sekolah bisa menjadi penyebab siswa bisa atau tidak dalam membaca Al-Quran. Faktor yang lain yang menjadi penyebab adalah pendidikan yang diterapkan orang tua saat dirumah. Sedangkan, dalam penerapan kurikulum 2013, siswa dituntut aktif dalam proses pembelajaran. Bagaimana siswa mampu aktif dan menguasai materi jika siswa tidak mempunyai dasar dalam membaca Al-Quran ? maka penelitian ini akan berusaha mengungkap solusinya.

Lingkungan keluarga adalah lingkungan dalam lingkup pertama yang diterima individu, karena dalam lingkungan ini anak mendapatkan bimbingan yang pertama. Lingkungan pendidikan keluarga adalah lingkungan pendidikan yang utama karena disinilah pondasi kehidupan diajarkan dan dalam lingkungan keluarga inilah anak sebagain besar menghabiskan waktunya. Sehingga, pendidikan yang paling banyak diterima dan diajarkan adalah dalam lingkungan pendidikan keluarga. ${ }^{21}$ Maka jika dalam pendidikan keluarga anak sejak dini tidak dikenalkan huruf hijaiyah sebagai pondasi awal untuk bisa membaca Al-Quran,

${ }^{21}$ Hasbullah, Dasar-dasar Ilmu Pendidikan (Jakarta: PT. Raja Grafindo, 2003) , hlm. 38. 
maka sewaktu mereka besar akan kesulitan dalam membaca Al-Quran. Dua faktor tersebut, yaitu asal sekolah dan pendidikan dalam keluarga akan menimbulkan kesenjangan kamampuan baca Al-Quran siswa di SMA Budi Mulia dua Yogyakarta.

Kita tahu bahwa pendidikan itu terjalin harmonis jika bisa selaras antara pendidikan dirumah, sekolah, dan masyarakat. Tiga hal tersebut dinamakan lingkungan pendidikan. Lingkungan adalah suatu ruang yang digunakan manusia dalam melangsungkan eksistensi kehidupannya. Lingkungan yang baik menurut Islam, adalah lingkungan yang diridhai oleh Allah SWT. Contoh lingkungan yang diridhai adalah sekolah, madrasah, masjid dan lingkungan-lingkungan yang digunakan dalam kebaikan. Dan lingkungan yang dimurkai Allah adalah lingkungan yang digunakan untuk tempat maksiat. ${ }^{22}$

Kesenjangan kemampuan siswa dalam membaca Al-Quran menjadi hambatan dalam mengimplementasikan kurikulum khususnya kurikulum komponen strategi/metode dalam pembelajaran. Hal ini menjadi hambatan dikarenakan ketika ada siswa yang belum bisa membaca Al-Quran akan membutuhkan waktu yang lama untuk menunggu dia membaca Al-Quran. Dalam waktu yang lama ini, seharusnya sudah bisa digunakan untuk membahas isinya dan kandungannya. Dengan masalah seperti ini, maka akan berhubungan dengan alokasi waktu. Waktu yang sudah dialokasikan akan kurang karena dalam pengimplementasiannya terhambat oleh siswa yang belum mampu membaca $\mathrm{Al}$ Quran. Dalam konteks pembelajaran agama ini merupakan tantangan bagi sekolah untuk menyediakan program agar semua siswa mempunyai kesempatan yang sama mengembangkan pengetahuan yang dimiliki. Jika seorang guru tidak peduli dengan adanya siswa yang belum bias membaca Al-Quran, maka guru sama saja tidak memberikan kesempatan kepada siswanya untuk bias membaca Al-Quran. Sedangkan, jika dalam pembelajaran guru mengajari siswa yang belum bisa membaca Al-Quran, maka siswa yang sudah bisa membaca Al-Quran, akan merasa terabaikan. Hal inilah yang membuat pembelajaran tidak bisa memberikan kesempatan yang sama dan mengembangkan pengetahuan yang dimiliki.

\section{Solusi Dalam Menghadapi Pengimplementasian Kurikulum PAI Dalam KBM}

Hambatan yang dihadapi dalam proses pembelajaran, seharusnya disikapi dengan bijak oleh pihak-pihak yang terkait. Jika hambatan ini dibiarkan maka proses pembelajaran tidak akan mencapai pada tujuan pendidikan yang hlm. 262.

22 Beni Ahmad. Saebani. Ilmu Pendidikan Islam. Jilid I. (Bandung: Pustaka Setia, 2012), 
diharapkan. Maka dengan hambatan yang saat ini dihadapi oleh SMA Budi Mulia Dua Yogyakarta, solusi yang lakukan adalah dengan dua cara yaitu Gerakan Literasi Sekolah dan Quran Corner. Gerakan Literasi Sekolah (GLS) adalah gerakan yang dilakukan secara terintegrasi dengan pembelajaran sehari-hari. Ada beberapa kegiatan didalam GLS ini, namun peneliti akan membahas satu kegiatan saja yaitu Quran reading. Kegiatan Quran Reading dilaksanakan setiap hari diawal kegiatan pembelajaran. Setiap siswa membawa Quran terjemah yang dulunya sudah mereka dapatkan saat kelas X awal. Guru mata pelajaran yang saat itu berada dikelas, sebelumnya sudah mendapatkan panduan surat apa saja yang dibaca oleh guru PAI. Guru yang saat itu bertugas yaitu guru yang menjadi pengajar mata pelajaran pertama adalah yang memimpin jalannya GLS. Tidak hanya membaca suratnya, tetapi juga terjemahan dan kandungannya. Kegiatan ini sudah berjalan kurang lebih tiga tahun. Kegiatan ini menghasilkan siswa yang terbiasa membaca dan mencintai Al-Quran. Kelemahan kegiatan ini adalah tidak adanya bimbingan khusus bagi siswa yang belum bisa membaca Al-Quran, sehingga sekolah kemudian membuat kegiatan lain diluar sekolah untuk membantu melayani siswa yang kurang dalam hal kemampuan membaca AlQuran.

Kegiatan lain yang membantu siswa dalam mempelajari Al-Quran dan termasuk kegiatan utama adalah Quran Corner. Kegiatan ini dinamakan RENCANA PROGRAM PENGEMBANGAN PENDIDIKAN AGAMA ISLAM DI SEKOLAH "Program peningkatan interaksi siswa terhadap Alquran melalui program Alquran Corner dan Progam Keagamaan Harian SMA Budi Mulia Dua Yogyakarta" dari nama progam tersebut, kita tahu bahwa ada beberapa progam keagamaan lain, tetapi peneliti akan berfokus pada kegiatan Quran Corner sebagai solusi dari hambatan saat pembelajaran PAI dikelas. Kegiatan ini berfokus pada upaya peningkatan membaca alquran, menghafal, dan juga memahami Alquran. Diharapkan dengan kegiatan ini akan mampu mengkondisikan siswa untuk semakin dekat dengan Alquran. Kegiatan ini bertujuan untuk Siswa mampunyai kemampuan membaca, menghafal, dan memahami isi/kandungan Alquran. Dengan indikator (1) Siswa mampu membaca Alquran dengan baik dan benar. (2) Siswa mampu menghafal Alquran dengan semangat dan antusias. (3) Siswa mempunyai kemampuan memahami isi ayat-ayat Alquran yang telah ditentukan. Hasil yang diharapkan (1) Tumbuhnya sebuah lingkungan pembelajaran dimana para siswa secara keseharian dekat dengan Alquran. (2) Menjadikan Alquran sebagai bagian penting dalam aktifitas pembelajaran di lingkungan sekolah.Dalam pengimplementasian progam Quran corner, berikut langkah-langkahnya:

1. Persiapan 
a. Persiapan konsep Alquran Corner meliputi penurunannya dalam jadwal harian. Kegiatan dilakukan sebelum memulai pelajaran yaitu pada hari senin-jumat. Pada hari senin, kegiatan dilakukan pada pukul 07.25-07.50 WIB. Pada hari selasa, kegiatan dilakukan pada pukul 07.25-07.50 WIB dan pada pukul 14.45-15.30 WIB. Pada hari rabu dilakukan pada pukul 07.25-07.50 WIB. Pada hari kamis dilakukan pada pukul 07.25-07.50 WIB, sedangkan pada hari jumat dilakukan pada pukul 07.25-07.50 WIB.

b. Penentuan pengampu

Pengampu akan diisi oleh:

$>$ Ustadz dari PP Budi Mulia, PP Wahid Hasyim dan PP Luqmaniyah dengan jumlah keseluruhan 6 orang

Dan dilakukan Rapat Koordinasi yang bertujuan menyampaikan tujuan Alquran Corner dan kesepakatan pengguanaan metode dengan menyesuaikan peserta didik yang ada di SMA Budi Mulia Dua

c. Metode yang dipilih:

> Metode yang digunakan Alquran Corner di pagi hari adalah proses standarisasi bacaan dengan metode talaqqi dimana dewan asatidz memberi contoh bacaan yang benar.

> Untuk menyamakan Alquran yang dibaca adalah dengan menggunakan Alquran yang sama dan memilih ayat-ayat yang disesuikan dengan 5 pilar SMA Budi Mulia Dua (faith in Allah, respect, responsibility, dan cleanliness)

> Untuk materi Alquran Corner lebih diarahkan pada pendalaman ilmu fikih karena berdasarkan pengamatan yang ada banyak siswa SMA yang praktek fikihnya masih harus ditingkatkan. Dari tim pengembang memilih kitab Fikih Wadhih sebagai buku pegangan siswa. Kami berkeyakinan bahwa fikih adalah bagian dari Alquran sehingga nama kegiatan tetap Alquran Corner.

2. Pelaksanaan

Pelaksanaan Al-Quran corner dilakukan pada pagi hari dan sore hari setiap selasa. Pada pagi hari siswa belajar membaca al-quran, sedangkan pada hari selasa sore siswa mempelajari kitab Fiqih Wadhih. Yang perlu disiapkan dalam kegiatan ini yaitu, guru pendamping, Buku pegangan untuk asatidz: kumpulan ayat Alquran tentang 5 pilar SMA Budi Mulia Dua (faith in Allah, respect, responsibility, dan cleanliness, Siswa mempunyai Alquran yang standar: Alquran Miracle Reference.

3. Monitoring dan evaluasi

$>$ Menyusun instrumen monitoring

$>$ Menyususn instrumen evaluasi

$>$ Melaksanakan monitoring dan evaluasi

Melaksanakan tindak lanjut 


\section{Refleksi \\ Mencermati hasil pelaksanaan kegiatan}

\section{Penutup}

Teori hanya akan sekedar teori jika tidak diimplementasikan dalam kehidupan sehari-hari. Seperti halnya dalam proses pembelajaran PAI sendiri, membutuhkan pengimplementasian supaya teori yang diberikan bisa dibuktikan secara langsung. Tidak bisa dipungkiri bahwa proses pengimplementasian tidaklah semudah membalik telapak tangan. Dalam proses pengimplementasian, tentunya akan menghadapi hambatan-hambatan sebagai penghalang tercapainya tujuan pendidikan.

Tujuan, isi, evaluasi dan metode merupakan komponen dari kurikulum, yang saling terkait satu sama lain. Kurikulum sebagai guiding instruction juga merupakan antisipatori dan bukan hanya sebagai reportial. Oleh karena itu, kurikulum merupakan suatu hal yang sangat menentukan atau paling tidak sebagai antisipasi/pencegahan terhadap sesuatu yang akan terjadi. Dalam penelitian ini, fokus kurikulum yang dibahas adalah pada prosesnya, yaitu proses pembelajaran PAI dikelas.

Dalam proses pembelajaran Universalisme Islam (PAI) di SMA Budi Mulia Dua Yogyakarta. Menurut guru mata pelajaran PAI sendiri, hambatan terberat saat ini dihadapi adalah adanya kesenjangan antara siswa yang mampu membaca Al-Quran dan yang belum mampu membaca Al-Quran. Hal ini dikarenakan siswa-siswi yang bersekolah di sekolah tersebut sangatlah heterogen. Latar belakang siswa berbeda antara satu dengan yang lainnya.

Maka dengan hambatan yang saat ini dihadapi oleh SMA Budi Mulia Dua Yogyakarta, solusi yang lakukan adalah dengan dua cara yaitu Gerakan Literasi Sekolah dan Quran Corner. Kegiatan Quran Corner sebagai solusi dari hambatan saat pembelajaran PAI dikelas. Kegiatan ini berfokus pada upaya peningkatan membaca alquran, menghafal, dan juga memahami Alquran. Diharapkan dengan kegiatan ini akan mampu mengkondisikan siswa untuk semakin dekat dengan Alquran. 


\section{Bibliografy}

Azis, Rosmiaty. 'IMPLEMENTASI PENGEMBANGAN KURIKULUM'. Inspiratif Pendidikan 7, no. 1 (1 June 2018): 44. https://doi.org/10.24252/ip.v7i1.4932Bahri, Syamsul."Pengembangan Kurikul Dasar dan Tujuannya", Jurnal Ilmiah Islam FUTURA Vol. XI, NO. 1, Agustus 2011.

Bahri, Syamsul. 'PENGEMBANGAN KURIKULUM DASAR DAN TUJUANNYA'. Jurnal Imiah Islam Futura 11, no. 1 (3 February 2017): 15. https:// doi.org/10.22373/jiif.v11i1.61.

Dedy Mulyana, Metodologi Penelitian Kualitatif Bandung: PT Remaja Rosdakarya, 2004.

'GAGASAN IVAN ILLICH TENTANG PENDIDIKAN Dalam Buku DESCHOOLING SOCIETY. Baharudin Dosen Prodi PGMI Fakultas Tarbiyah Dan Keguruan..Pdf, n.d.

Hasbullah, Dasar-dasar Ilmu Pendidikan Jakarta: PT. Raja Grafindo, 2003.

Https://juharti.wordpress.com diakses pada 22 November 2019

Irsad, Muhammad. 'PENGEMBANGAN KURIKULUM PENDIDIKAN AGAMA ISLAM DI MADRASAH’ 2, no. 1 (2016): 39.

Kurniaman, Otang, and Eddy Noviana. 'PENERAPAN KURIKULUM 2013 DALAM MENINGKATKAN KETERAMPILAN, SIKAP, DAN PENGETAHUAN'. Primary: Jurnal Pendidikan Guru Sekolah Dasar 6, no. 2 (30 October 2017): 389. https://doi.org/10.33578/jpfkip.v6i2.4520.

Ma'rifataini, Lisa Diyah. 'IMPLEMENTASI METODE PEMBELAJARAN PENDIDIKAN AGAMA ISLAM (PAI) DI SEKOLAH MENENGAH ATAS NEGERI (SMA) 11 BANDUNG'. EDUKASI: Jurnal Penelitian Pendidikan Agama dan Keagamaan 16, no. 1 (2 May 2018). https://doi.org/10.32729/edukasi.v16i1.464.

Mahmud. Pemikiran Pendidikan IslamBandung: Pustaka Setia, 2011.

Margono, metodologi Penelitian Pendidikan Jakarta: Rineka Cipta,1997.

Muamanah, Hidayatul, and . Suyadi. 'Pelaksanaan Teori Belajar Bermakna David Ausubel Dalam Pembelajaran Pendidikan Agama Islam'. Belajea; Jurnal Pendidikan Islam 5, no. 1 (22 May 2020): 161. https://doi.org/10.29240/belajea.v5i1.1329. 
Muchtar, Achmad Dahlan. 'IMPLEMENTASI KURIKULUM PAI 2013 PADA ANAK BERKEBUTUHAN KHUSUS DI SMPLB BHAKTI KENCANA YOGYAKARTA'. Edumaspul - Jurnal Pendidikan 2, no. 1 (28 February 2018): 70-78. https://doi.org/10.33487/edumaspul.v2i1.16.

-Muhibin, Muhibbin, and M. Arif Hidayatullah. 'Implemntasi Teori Belajar Konstruktivisme Vygotsky Pada Mata Pelajaran Pai Di SMA Sains Qur`An Yogyakata'. Belajea; Jurnal Pendidikan Islam 5, no. 1 (22 May 2020): 113. https://doi.org/10.29240/belajea.v5i1.1423.

Moleong, Lexi J. Metode Penelitian KualitatifBandung: PT Remaja Rosdakarya, 2005.

Ramayulis, Ilmu Pendidiakan Islamjakarta: Kalam Mulia, 2015.

Saebani. Beni Ahmad. Ilmu Pendidikan Islam. Jilid I. (Bandung: Pustaka Setia, 2012.

Salahuddinn, Anas. Filsafat Pendidikan Bandung: Pustaka Setia, 2011.

Siswanto, Siswanto, and Eli Susanti. 'Manajemen Pengembangan Kurikulum Sekolah Inklusi'. Tadbir: Jurnal Studi Manajemen Pendidikan 3, no. 2 (24 November 2019): 113. https://doi.org/10.29240/jsmp.v3i2.927.

Tafsir, Ahmad. Imu Pendidikan Islami Bandung: Remaja Rosdakarya, 2016.

Udin Syaefudin dan Abin Syamsudin Makmun, Perencanaan Pendidikan Bandung: Remaja Rosdakarya, 2005.

Ulfah, Humaira, Edi Suresman, and Abas Asyafah. 'STUDI REALITAS IMPLEMENTASI KURIKULUM 2013 PADA MATA PELAJARAN PAI DAN BUDI PEKERTI JENJANG SMA (Studi Deskriptif pada Berbagai Klasifikasi Guru SMA di Kota Bandung Tahun 2015)'. TARBAWY : Indonesian Journal of Islamic Education 2, no. 1 (5 May 2015): 58. https://doi.org/10.17509/t.v2i1.3378. 
198 | Belajea: Jurnal Pendidikan Islam, Vol. 5, No. 2, 2020 